\title{
Tarihten Günümüze Kur’an ile Yetinme Söyleminin Kritiği*
}

\section{Criticism of the Discourse of Confining Oneself to the Quran From History to Today}

\author{
Recep Aslan a, ** \\ ${ }^{a}$ Prof. Dr. Gaziantep Üniversitesi, İlahiyat Fakültesi, Temel İslam Bilimleri Bölümü, Hadis Anabilim Dalı, Gaziantep/Türkiye. \\ ORCID: 0000-0002-7541-0405.
}

\begin{tabular}{l} 
MAKALE BİLGİSİ \\
Makale Geçmişi: \\
Başvuru tarihi: 30 Mart 2021 \\
Düzeltme tarihi: 20 Haziran 2021 \\
Kabul tarihi: 6 Temmuz 2021 \\
\hline Anahtar Kelimeler: \\
Kur'an, \\
Kur'an İslâm'1, \\
Sünnet, \\
Kur'an ile yetinme, \\
Hadis İnkârı
\end{tabular}

\section{A RTICLE INFO}

\section{Article history:}

Received: 30 March 2021

Received in revised form: 20 June 2021

Accepted: 06 July 2021

Keywords:
The Qur'an,
Qur'an' Islam,
Sunnah,
Making Do with the Qu'ran,
Hadith Denial

ÖZ

Kur'an ile yetinme söylemi/Hadisi inkâr düşüncesi, her dönemde az veya çok Müslümanların gündeminde olmuş bir meseledir. Çağımızda sünnete karşı olumsuz tavır takınan marjinal gruplar olduğu gibi, tarihi süreç içerisinde de sünneti kabul etmeyen, İslâm'ın sadece Kur'an'dan ibaret olduğunu gizli veya açıkça iddia eden "Kur'an İslâm'ı" veya "Kur'an Müslümanlığı” şeklinde birtakım isimlerle kendini nitelendiren kesimler olmuştur. Kur'an ile yetinme söyleminin birtakım çıkmazları vardır. Sadece Kur'an ile yetinme demek, Hz. Peygamber'in tebyîn görevini elinden alıp sadece tebliğ görevi ile iktifa etmek anlamına gelir. Bu söylemi dillendiren çevreler, Hz. Peygamber'in konumu ile alakalı âyetleri parçacı yaklaşımla işlemekte, Hz. Peygamber' in statüsünü adeta bir postacı durumuna indirgemektedirler. Kur'an ve sünnetten birini kabul etmemek dinin bir kısmını kabul edip diğer bir kısmını inkâr etmek anlamına gelir. Bu çalışmada, Kur'an ile yetinme söyleminin tarihi arka planına ve günümüze yansımasına ana hatlarıyla değinilecektir.

\section{Giriş}

Kur'an ile yetinme söylemi/Hadisi inkâr düşüncesi, her dönemde az veya çok Müslümanların gündeminde olmuş bir meseledir. Çağımızda sünnete karşı olumsuz tavır takınan marjinal gruplar olduğu gibi, tarihi süreç içerisinde de sünneti kabul etmeyen, İslâm'ın sadece Kur'an'dan ibaret olduğunu gizli veya açıkça iddia eden “Kur'an İslâm'ı" veya
“Kur'an Müslümanlığı” şeklinde birtakım isimlerle kendini nitelendiren zümreler olmuştur.

Bu çalışmamızda Kur'an ile yetinme söyleminin tarihi arka planına ana hatlarıyla değinip kısa bir değerlendirmeyle iktifa edeceğiz.

\footnotetext{
* Bu çalışma, 7 Aralık 2020 tarihinde Muş Alparslan Üniversitesi İslami İlimler Fakültesinde düzenlenen İslam Düşüncesinde Eleştiri Kültürü ve Tahammül Ahlâkı II (Klasik Dönem- M. VII.- XII. Yüzyıllar) Sempozyumunda sunulan bildirinin geliştirilmiş halidir.

**Sorumlu Yazar/Corresponding author.

e-posta: raslan@gantep.edu.tr 


\section{Tarihi Arka Plan}

Hicri 2. asırdan itibaren bazı grupların Kur'an'la yetinme düşüncesini ortaya attıkları ve dolayısıyla hadisi/sünneti reddetmeye başladıkları görülmektedir. Hadis kaynaklarında yer alan aşağıdaki rivâyet konunun önemi açısından dikkat çekicidir:

Hz. Peygamber (s.a.v.) şöyle buyurmuştur: "Bilin ki, bana Kur'an ile birlikte onun bir benzeri de verilmiştir. Karnı tok bir şekilde koltuğuna kurulmuş olan bazı kimselerin '(Sadece) bu Kur'an'a sarılın; Kur'an'ın helal dediğini helal, haram dediğini haram kabul edin.' diyeceği zamanlar yakındır. Bilin ki, Allah'ın Resûlünün haram kıldıkları da Allah'ın haram kıldıkları gibidir" (Ebû Dâvûd, 1999: Sünne, 6; Tirmizî, ts: İlim, 10; İbn Mâce, ts: Mukaddime, 2; Ahmed b. Hanbel, 1995: 28/410-411).

Bu rivâyette de görüldüğü gibi sadece Kur'an'la yetinme ve sünnete önem vermeme eğiliminin izlerinin İslâm'ın ilk dönemlerine kadar uzandığı ortaya çıkmış olmaktadır.

Kitlesel anlamda hadislere karşı ilk menfi yaklaşıma sahip olan topluluğun Haricîler olduğu söylenebilir. Haricilerin hadisleri inkâr ettikleri söylense de bunun bütün hadisleri kapsadığını söylemek mümkün değildir. Genel anlamda hadisleri inkâr etmemekle birlikte, fitne olaylarına karıştıklarından dolayı çoğu sahâbenin rivâyetlerini kabul etmemişlerdir. Kendi düşünce yapılarına uymayan hadisleri çok kolay bir şekilde reddetmişlerdir (Çakın, 1998: 98). Haricîler içerisinde İbâdîler gibi Ehl-i sünnete yakın gruplar da vardır. İbâdiyye mezhebinin önemli imamlarından olan Rebî' b. Habîb'in (ö. 180/796) el-Câmiu's-Sahîh adlı eseri, İbâdiyye mezhebi nezdinde Kur'an'dan sonra en sahih ve muteber kaynak olarak kabul edilmektedir (Özdemir, 2018: 2).

İkinci sırada ise Şia mezhebi gelmektedir. Bunların içerisinde de aşırı giderek hadisleri reddedenler olmakla birlikte, genel anlamda hadisleri tamamiyla reddettikleri söylenemez. Bunlar her hadisi almak yerine Ehl-i Beytten gelen hadisleri almayı tercih etmişlerdir. Başka bazı sahâbîlerden de kendi görüşleri ile çelişmeyen rivâyetleri kabul etmişlerdir.

Mutezile mezhebi de genel manada hadisi inkâr etmemekle birlikte metin tenkidi adı altında bazı hadisleri reddetmişlerdir. Ehl-i Hadis sened tenkidine önem verirken Mutezile metin tenkidine önem vermiş, râvîlerin mutezilî ve kelâmcı olmasını tercih etmiştir (Çelik, 2019: 78-79. Ayrıca bk. Çakın, 1998).

Mezheplerin dışında, bazı kişilerin hadislere karşı şüphe ile baktıkları ve Kur'an'dan başka bir kaynağı kabule yanaşmadıklarına rastlanılmaktadır. Sahâbeden İmrân b. Husayn (ö. 52/672) ile sünnet konusunda tartışan şahsın durumu bunun örneklerinden birisidir. İmrân b. Husayn, Hz. Peygamber'in sünnetinden söz ederken birisi araya girerek sünneti küçümser vaziyette "Ey Ebû Nüceyd bize Kur'an'dan bahset!" demiştir. Bunun üzerine İmrân b. Husayn kişiye şu yanıtı vermiştir: Sen ve arkadaşların Kur'an'1 okumuyor musun, bana namazin nasil eda edileceğinden, zekâtın ne tür mallardan verileceğinden vb. konulardan bahsedebilir misin? İmrân bu tür açıklamalarla adamı susturmuştur (et-Taberânî, 1404/1983: 18/166; Hâkim en-Nîsâbûrî, ts.: 1/109-110).
$\mathrm{Bu}$ rivâyette henüz sahâbenin yaşadığı dönemde sünnete gerek olmadığı, yalnız Kur'an ile yetinilebileceği fikrinin ilk izlerini görmek mümkündür.

İlk dönemlerdeki hadislere karşı bu olumsuz yaklaşım kitlesel değil bireysel, evrensel değil yöreseldi. Fakat bu düşünce, zamanla genişleyerek toplumsal bir hale dönüştü. Yer yer ve dünyanın çeşitli bölgelerinde bu düşünce dillendirilmeye başlanmıştı. Hadislere karşı ortaya çıkan ilk kimseler Irak bölgesindendi. Eyyûb es-Sahtiyânî (ö. 131/749) Basra'lıydı. İmrân b. Husayn ile tartışan kişi Iraklıydı. Yine İmâm Şâfiî’nin (ö. 204/819) söz ettiği, sünneti delil olarak kabul etmeyenlerin çoğunluğu Basra'lıydı (A'zamî, 1987: 434; Çelik, 2019: 79). İmam Ebû Hanife'nin (ö. 150/767) yanında hadis okunurken Kufeli biri girdi ve: "Bu hadisleri bırakın" dedi. Ebû Hanife ona şiddetli bir şekilde kızarak şöyle dedi: "Eğer sünnet olmasaydı bizden hiç kimse Kur'an'1 anlayamazdı" (Irakî, 1410/1990: 15). Bu çeşit örneklerden hareketle, ilk dönemde sünneti inkâr edenlerin genelinin Irak merkezli olduğu söylenebilir.

İmâm Şâfîî’nin (150/767-204/820) yaşadığı zaman dilimine bakıldığında Kur'anla yetinme ve sünneti red eğiliminin bu dönemde de olduğu görülmektedir. Yani hadis inkârcılığının 8. yüzyılın sonları ve 9. yüzyılın başlarında yaygın bir görüş haline geldiği anlaşılmaktadır. İmâm Şâfî̂, el-Umm adlı eserinin “Cimau'l-İlim" bölümünde, bu konuya yer vermiştir (Şâfîi, 1422/2001: 9/5-42). Şâfî̀, yaşadığı çağda sünnete karşı oluşturulan olumsuz hareketleri üç kısımda toplamaktadır: Ona göre, birinci grupta olanların iddiası şu şekildedir: Kur'an her şeyi beyan etmiştir. Onun vasfi da budur. Hadis ise insanlar tarafindan aktarılmaktadır. Hal böyle iken, sünnet, teşrîde Kur'an'a karşı nasıl denk kanıt olarak kabul edilir. Kur'an'ın hadise gereksinim duymadığı ve hadis râvîlerinin, unutkanlık, hata ve yalandan uzak olmamaları nedeniyle hadisin teşrîde yerinin olmadığı fikri iddia edilmektedir. İkinci grubun görüşü de şu şekildedir: Bir konuda aktarılan rivâyetler, sadece Kur'an tarafindan o konuda izah yapılmış ise kabul edilir. Bunun dışında kalanlar reddedilir. Yani sünnetin Kur'an'a ek hüküm getiremeyeceği iddia edilerek sünnet kısmen devre dışı bırakılmaktadır. Üçüncü fikre göre ise, sadece mütevatir rivâyetler kabul edilmeli, haber-i vâhid rivâyetler ise inkâr edilmelidir. Bu grubun görüşüne göre de rivâyetlerin bütününe yakın bir kısmı reddedilmiş olmaktadır (Şâfî̂, 1422/2001: 9/5-42 (Özetle aktarılmıştır.); Sancaklı, 2013: 114-115).

İmâm Şâfiî, bu grupların görüşlerini nakletmekle beraber bu görüş müntesiplerine cevaplar da vermiştir. Fakat Şâfî̂, bu görüş müntesiplerinin kimler ve hangi mezhepten olduğu konusunda herhangi bir açıklama yapmamıştır. Bunların kimlikleri konusunda tarihî süreç içerisinde pek çok tartışma olmuştur. Eserinde bu tartışmaları işleyen Hüseyin Hansu, bazı araştırmacıların, hadisleri reddeden bu kimselerin Mu'tezileden olduğunu, bu nedenle bu mezhep müntesiplerinin rivâyetleri bütünüyle kabul etmediğini iddia ettiklerini ama bu görüşün hakikati yansıtmadığını söylemekte ve Mu'tezilenin hadisleri bütünüyle reddetme gibi bir tavrının olmadığı kanaatini ifade etmektedir. Söz konusu çalışmasında Hansu, hadisleri toptan inkâr eden firkaların bazı Haricî grupları olma ihtimalinin olduğunu söylemektedir (Hansu, 2004: 305-307).

Hansu'ya göre, Haricilerin en azından bazı grupları, sünneti inkâr etmektedir. Dolayısıyla Şâfîînnin bahsettiği 
rivâyetlerin bütününü inkâr eden grubun Mu’tezile değil, Haricilerin bazı firkaları olması muhtemeldir (Hansu, 2004: 308). Mustafa el-A'zamî de Mu'tezilenin ümmetin cumhuru gibi hadisleri delil olarak kabul ettiğini, görüşlerine uymayan bazı hadisleri reddetmiş olsalar da içlerinde hadisleri bir bütün olarak reddeden kimsenin olmadığını ifade etmiştir (A'zamî, 1413/1992: 1/25).

\section{XIX. Asır ve Sonrası Hadisi İnkâr Düşüncesi}

Hicri ikinci asrın sonlarına yakın zamanlarda sünneti red ve inkâr yanlısı küçük bir grubun mevcut olduğu ve bu grubun ikinci asrın sonuna veya en çok üçüncü asrın ortalarına kadar kalabildikleridir. Bu tarihten sonra bunların ardından hiç kimsenin bu işe kalkışmadığı müşahede edilmektedir. İslâm dünyası on bir asır gibi uzun bir zaman diliminde bu fitneden yana güvende yaşamıştır. $\mathrm{Bu}$ durum, sömürgecilik döneminin bidâyetiyle sona ermiştir. Hadisleri inkâr düşüncesinin 19. yüzyılda zirve yaptığını söyleyebiliriz. Bu asırda sömürgeciler, İslâm üzerine baskın olmak için ve Müslümanları bölüp, nizamlarını yıkarak darmadağın etmekten ibaret olan emperyalist projelerinin gerçekleşmesi namına fikir ve görüşlerini serpmeye başladılar. Sömürgeciler, sünnete saldırarak, Onun delil oluşunda, sünneti tedvin edip, aktaranların samimiyetinde kuşkular uyandırmaya çaba göstermişlerdir (Hekim, 1985: 39-40).

19. yüzyıl İslâm coğrafyasının mühim medeniyet merkezlerinin istilaya uğradığı bir asırdır. Bu merkezlerden ikisi ilgi çekicidir: Hindistan ve Misır. Hindistan 1849, Mısır ise 1882 yılında İngiliz işgaline maruz kalmıştır. Bu işgallerden önce de her iki merkez başta Fransa ve İngiltere olmak üzere batılıların nüfuz ve mücadele bölgeleri idi. İşgalle beraber bu iki mıntıkada yaşayan kişiler, batının gücüyle ilk defa bu denli yakınlaşmış ve sömürgecilerle beraber yaşamak durumunda kalmışlardır. $\mathrm{Bu}$ durum neticesinde tek taraflı bir etkilenme söz konusu olmuştur. Sömürgecilerle yüzleşme peşinden sorgulamayı getirmiştir. Her iki ülkede, Müslümanların düştükleri yerden kalkmaları, batılılar gibi kalkınmaları, fikri durgunluğun içinden çıkmaları ve en önemlisi de İslam' 1 cihanşümul bir din olarak başta kendilerine sonra da bütün insanlığa arz etmenin metot ve yöntemleri araştırılmaya teşebbüs edilmiştir. Müslümanların gelişmesinin önündeki engeller tespit edilerek bunların yok edilmesi gerektiği düşünülmüştür. Bu yaklaşım tarzı Müslümanları Kur'an etrafında bir araya getirmeye, onu yeniden yorumlamaya yöneltmiştir. Hadisler ise birtakım sebeplerle ya önemli oranda eleştiriye maruz kalmıştır veya bütünüyle terk edilmesi gerektiği dillendirilmiştir (Yıldırım, 2003: 179).

Ebû'l-A'lâ el-Mevdûdî (ö. 1979), sünnet inkârcılığının kronolojik seyrini verdikten sonra çeşitli değerlendirmelerde bulunmuştur. Mevdûdî'ye göre İslâm düşüncesi, yabancı felsefe ve gayr-i Müslim medeniyet ve kültürle karşılaşınca dışarıdan gelen tüm görüş ve akımları eleştirmek yerine, bütünüyle akla ve mantığa uygun kabul ederek, İslam'1 bunların kalıbına dökmeye kalkışmıştır (Mevdûdî, 1997: 8). Sünnet inkârcıları, bu maksatla sünneti ortaya koyan rivâyetlerin doğruluğuna şüphe düşürmeye ve bizzat sünnetin hücciyetini inkâr etmeye çaba göstermiştir (Mevdûdî, 1997: 9). Neticede Resûlullah'ın nübüvvet makamını bir ulak veya postacı seviyesine indirgeyip, onun görevinin sadece Kur'an'1 insanlara iletmek olduğunu vurgulamışlardır. Sadece Kur'an'ın teşri kaynağı olduğunu, sünnetin ise teşri kaynağı olmadığını söylemişlerdir (Mevdûdî, 1997: 11).

\subsection{Hindistan}

Müsteşriklerin sünnetle ilgilenmeleri 1800'lü yıllarda başlamış (Çelik, 1997: 33) ve bu konudaki çalışmaların ilk etkileri, İngilizlerin işgal ettiği Hindistan ve Mısır'da kendini göstermiştir. İlk önce Hindistan'da hadis ve sünneti tamamen reddeden bir düşünce (Kur'aniyyûn) ortaya çıktı. $\mathrm{Bu}$ düşüncenin ilk temsilcisi Kadiyanî tarikatının öncülerinden Seyyid Ahmed Han (ö. 1898), Çırağ Ali (ö. 1898), Abdullah Çekralevî'dir. Daha sonra bu düşünce, Ahmeduddin Amritsarî (ö. 1936) ve Eslem Ceracpûrî (ö. 1955) ile sürdürülmüştür. Son olarak bu görevi Gulam Ahmed Perviz (ö. 1985) üstlenmiştir (Görmez, 2000: 89).

Kendilerini Ehl-i Kur'an olarak isimlendiren bu kimseler, birçok konuda farklı görüşte olsalar da; Kur'an'la yetinme ve sünnetin dinde hüccet olamayacağı gibi iki konuda fikir birliği etmişlerdir. Bu firka daha da ileri giderek "Her kim Allah'ın indirdiği ile hükmetmez ise kâfirlerin ta kendileridir." (el-Mâide 5/44) âyetini delil getirerek sünnetle amel edenin kâfir olacağını söylemişlerdir (Görmez, 2000: 89-90). Bunların peşinden giden birçok genç, sünnete yani Hz. Peygamber'in açıklamalarına başvurmadan, Kur'an'1 daha iyi anlayacaklarını savunmuş ve Kur'an'dan ilginç istinbâtlarda bulunmuşlardır (Nedvî, 2002: 274).

Kur'an'ın dini anlamak için esas olduğunu, sonradan tedvin edildikleri için hadislere ise, güvenilemeyeceğini ileri süren Seyyid Ahmed Han, hadisçilerin sened tenkidiyle ilgilenip metin tenkidiyle ilgilenmediklerini iddia eder (Yıldırım, 2003: 180). Aynı ekolün mümessillerinden Abdullah Çekralevî'ye göre de "Yüce Allah'ın kitabı kâfidir. Çünkü o mükemmel ve tafsilatlıdır. Herhangi bir şerhe ve peygamberi tefsire ihtiyaç yoktur.” (Daudî, 1995: 277).

Hz. Peygamber'in vazifesinin sadece Kur'an'1 ulaştırmak olduğunu ifade eden Pervîz ise Hz. Muhammed'e (s.a.v.) tabi olmaya gerek olmadığını, çünkü Kur'an'da 'size indirilene tabi olun' emrinin bulunduğunu belirtir. Ona göre, şayet sünnet dinde bir niteliğe sahip olsaydı, Hz. Muhammed (s.a.v.) 'Benden Kur'an'dan başka bir şey yazmayın' hadisini söylemezdi. Bu doğrultuda Kur'an'a uygun hadis sadece sahih hadistir (Daudî, 1995: 278). Pervîz, kendisinin müçtehit olduğunu iddia ederek sadece Kur'an'ın delil olabileceğini ve onun dişında sünnetin mütevatir dahi olsa delil olamayacağını söylemiştir. Namazın vakitleri, rekâtları ve nasıl kılınacağı gibi hususları ise devlet başkanına bırakmıştır. Devlet başkanı bu gibi hususları danışmanlarına istişare ederek nasıl ve ne tarzda yapılacağını belirler (A’zamî, 1987: 441).

Görüldüğü gibi, Kur'aniyyûn ekolüne mensup olanların bir kısmı hadisleri bütünüyle reddederken diğer bir kısmı ise hadislere son derece şüpheci yaklaşmakta, ihtiyatlı oluşlarını da yine hadislere dayandırmaktadirlar. Dolayısıyla Kur'aniyyûn ekolüne mensup herkesin hadisleri tamamen reddettiği söylenemez (Kırbaşoğlu, 2016: 120; Yıldırım, 2003: 181. Ayrica bk. Bilgin, 2018: 277-282).

Aynı dönemde Hindistan'da Ehl-i Kur'an'a karşı, aynı aşırılıkta hadislere düşkünlük gösteren Ehl-i Hadis 
doğmuştur. Bunlar da Kur'aniyyûn ekolünün aksine hadis metinlerini, hasta ziyaretlerinde şifa, cenazelerde bağışlama niyetiyle okuyacak kadar kutsallaştırmıştır. Senedlerle birlikte hadis ezberlemeyi ise yeniden alışkanlık haline getirmişlerdir. Görmez'e göre bu iki kesimin tartışmalarından birçok olumlu görüş ve çalışmaların da ortaya çıktığını söylemek mümkündür (Görmez, 2000: 90).

\subsection{Misir}

Mısır'da da aynı dönemde ve aynı endişelerle Kur'an etrafında bir araya gelme ve tecdit hareketi başladı. İlk olarak Cemaleddin Efgânî (ö. 1897) tarafından el-Medresetu'lIslahiyye veya Modern Rasyonalizm Ekolü ve Sünnet adı altında İngiliz sömürgeciliğine karşı bir ekol oluşturuldu (Eren, 2000: 53). Efgânî'nin Kahire'de başlattığı bu hareket, bütün insanlığı İslam'1 yenilenmeye davet etti. Ardından talebesi Muhammed Abduh'la (ö. 1905) beraber, sürgünde bulundukları Avrupa'da neşriyat yoluyla Müslümanları öz kaynaklarından beslenerek İslami uyanışa, bid'at ve hurafelerden kaçınmaya, sömürgeden kurtuluşa çağırdı. Misır'a döndükten sonra başlatılan İslâmî tecdid hareketinin önderliğini üstlenen Abduh'un mesaj ve çalışmaları bütünüyle Kur'an merkezli idi. Başka tefsir çalışmalarında görüldüğü gibi onun "Menar" tefsirinde de müsbet bilimlerin ağırlığı ve Kur'an'ın modern bilimlerle uzlaştırılması kendini göstermektedir.

Abduh, ateşli bir içtihat taraftarı olarak insanlara taklitten kurtulmayı, geçmiştekilerin donuk fikirlerine saplanmamayı tavsiye etti. Abduh'un nazarında haberlerin Buhârî (ö. 256/870) ve Muslim'in (ö. 261/875) el-Câmi 'u'sSahîh'lerinde veya diğer muteber hadis kaynaklarında oluşu bir değer ifade etmemekteydi. Menar dergisini çıkaran Abduh'un talebesi Reşîd Rizâ (ö. 1935) İslâm'ın modern dünyaya ayak uydurmasını isteyip kadınlara medeni hakların verilmesi, çok evliliğin yasaklanması gibi istekleri seslendirmesinin yanında dergi kanalıyla hadis ve sünneti Mısır'da o dönemde dini tartışmanın merkezine çekmiştir (Yildirım, 2003: 182).

Reşî̀ Rizâ'dan sonra talebeleri de sünneti tamamen reddetmişlerdir. Bunların başında "Sünnetsiz İslâm" sloganıyla ortaya çıkan Mirzâ Bakır gelir. Mirzâ Bakır'ın bu fikirlerini ilk kez tartışma sahnesine koyan kişi ise bir tıp doktoru olan Muhammed Tevfik Sidkî'dir (ö. 1920). O'nun “el-İslâmu Huve'l-Kur'ânu Vahdeh (İslâm sadece Kur'an'dır)" adlı makalesi "el-Menâr" dergisinde yayınlanınca Mısır'da görülmemiş bir tartışma başlar (Görmez, 2000: 90). Sidkî, Kur'an metninin tek olduğunu, hadislerin ise $\mathrm{Hz}$. Peygamber'in vefatından sonra yazıldığını, bunun içlerine onlardan olmayan malzemenin karışmış olabileceğini, mevcut hadisler arasında oldukça farklılık arz eden durumların da bunu teyid ettiğini; müctehidlerin hadislere baktıklarında çoklarının mevzû olduklarını gördüklerini, kendi görüşünü ortaya çıkarmak için de hadislerin bir kısmını atmak durumunda kaldıklarını ve tüm gayretin Kur'an'a yönlendirilmesi gerektiğini belirtmiştir (Yıldırım, 2003: 182; Demir, 2002: 76; Çelik, 2019: 84).

İsmail Edhem ise 1934 yılında neşrettiği bir broşürde "Sahihan"dakileri de içine katarak bütün hadislerin asıllarının ve temellerinin sabit olmadığını iddia etmiştir. Benzer iddiaları, Ahmed Emin (ö. 1954) Fecrü'l-İslâm'ında,
Mahmud Ebû Reyye (ö. 1970) Advâun ale's-Sünneti'lMuhammediyye'sinde, Ahmed Zeki Ebû Şâdi'nin (ö. 1955) Sevretü'l-İslâm adlı eserlerinde görmek mümkündür (Yıldırım, 2003: 183; Çelik, 1997: 34. Ayrıca geniş bilgi için bk. Hekim, 1985: 57-82). Taha Huseyn (ö. 1973), Hasan Hanefi gibi şahsiyetler de bu çizgiyi takip etmişlerdir (Y1ldırım, 2003: 183).

\subsection{Türkiye}

20. yüzyılın son çeyreğine kadar Türkiye'de hadis etrafında yoğun tartışmalar olduğunu söylemek mümkün gözükmemektedir. 1926 yılında Daru'l-Funûn İlahiyat Fakültesi Mecmuası'nda yazmış olduğu Dinî ve Gayr-1 Dinî Rivâyetler adlı makalede hadislerin tespitinde senede önem verildiğini ve metnin ihmal edildiğini, hadislerin yeterince tenkide tabi tutulmadığını ilk söyleyen kişi Zakir Kadirî'dir (ö.1954). Ülkemizde hadis tenkidinin ciddi anlamda M. Said Hatiboğlu ile başladığı söylenebilir. Onun başlattığ 1 bu hareket gerekli bilimsel şartları yerine getirmek suretiyle İlahiyat Fakülteleri başta olmak üzere hadis alanında yapılan çalışmalarda kendisini göstermektedir (Yıldırım, 2003: 183).

$\mathrm{Bu}$ metodik çalışmaların yanında bütün hadis mecmuasını reddedenler de vardır. Örneğin Edip Yüksel, 'Kur'an'dan başka hangi hadise inanıyorsunuz?" başlığı altında tenkitlerini sıralamıştır. Ona göre, Yahudilerin yaptığı gibi, Müslümanlarda Hz. Peygamber'in vefatından sonra uydurdukları binlerce yalanı Hz. Peygamber'e isnad ettiler. Bu uydurma dini kaideleri, tıpkı Yahudilerin yaptığı gibi sünnet (pratik) ve hadis (söz) olarak isimlendirdiler. Cahil kimseler Kur'an'da tenkit edildiği şekilde çeşitli sorular sorup yanıt beklediler. Mesela uyurken hangi tarafa yatmak gerektiği, sakalın ne kadar uzatılacağı, yemekleri hangi elle yemenin daha faziletli olacağı, hangi meyve ve sebzeleri yemenin daha sevap olacağı gibi sorulara cevap üretmeye başladılar. Bu şekilde saçma sorularının yanıtını Kur'an'da bulamayınca Hz. Peygamber'in ağzından yanıtlar uydurmaya başladilar. Hurafe ve çelişkiler ile dolu bu uydurma nakiller üzerinde tartışıp mezhep mezhep bölündüler. Münafiklar bu durumdan istifade ederek yüz binlerce rivâyet uydurdular. Yüksel'e göre, ilgi çekicidir ki Hz. Peygamber'in bir numaralı hasmı olan Buhârî, Hz. Peygamber'e hakaret ve iftiralarla dolu eserini $\mathrm{Hz}$. Peygamber'in ölümünden iki yüzyıl sonra telif etmiştir (Yüksel, 2016: 21-22). Yüksel, aynı zamanda 'Kur'an'1n yanında sayısız hadis kitapları" başlığı altında da Kütüb-i Tis'a'yı Kur'an'a ortak koşulan kitaplardan saymıştır. Ona göre, sünnî mezhepler genellikle altı hadis kitabının "en sahih" eserler olduğuna kanaat ederler. Bu eserlere ek olarak Mâlik b. Enes'in (ö. 179/795) el-Muvatta'1, Ahmed b. Hanbel'in (ö. 241/855) el-Müsned'i ve Dârimî'nin (ö. 255/869) es-Sünen'i de itimat ettikleri ve Kur'an'a ortak koştukları eserlerdendir. Yazar daha ileri giderek sünnî âlimlerin Buhârî'nin el-Câmiu's-Sahîh'inde geçen Kur'an ile çelişen rivâyetlerini Kur'an'a tercih etmekte tereddüt etmediklerini iddia etmiştir. Yüksel, Hanefi mezhep bilginlerinin hadis ile Kur'an çeliştiğinde hadisin Kur'an'ın hükmünü iptal edebileceğini ileri sürdüklerini ve Hanefilerin bunu bir mezhep görüşü olarak kişilere dikte ettiklerini söylemiştir (Yüksel, 2016: 26). Eserinin kimi yerlerinde sahâbeye de dil uzatmış ve Ebû Hureyre gibi bir sahâbînin sabıkalı bir yalancı olduğunu ifade etmiştir (Yüksel, 2016: 28). 
Ülkemizde, hadis birikimi olmadan rivâyetler hakkında toptan genellemelerde bulunan, ele aldığı çeşitli hadislerle bütün hadis külliyatını karalayan başkaları da vardır. Örneğin Emre Dorman eserinde "Hadisler Neden Dinin Kaynağı Olamazlar?” adlı bir bölüm yazmıştır. Hadislerin birçoğunun güvenilir olmadığını ileri sürerek görüşlerini ise şöyle ifade etmiştir: "Hadisler dinin kaynağı olamaz. Çünkü örnek verilen birçok âyette net bir şekilde görüldüğü gibi dinin tek kaynağı vardır. O da Kur'an'dır. Allah dinini Kur'an vahyi ile bildirerek tamamlamıştır. Hadis rivâyetleri hem Kur'an ile hem kendi aralarında hem de akıl ve mantık kuralları ile çelişiyor olmasaydı yine de dinin kaynağı olamazlard1. Allah'in dinine uymak isteyen Allah'1n belirlediği ile yetinmelidir." (Dorman, 2018: 91). Yazar, Muhammed Abduh, Mahmud Ebû Reyye gibi Misırlı yazarlardan etkilenerek başta Kütüb-i Sitte olmak üzere hadis kaynaklarını itibarsızlaştırıp ciddi tenkitler yöneltmektedir. Ona göre, "Söz konusu kitaplardaki birçok hadis, hem Kur' an ile hem kendi aralarında hem de insan aklı ve yaratılışı ile çelişmekte ve dini tam anlamıyla anlaşılmaz, içinden çıkılmaz ve yaşanılmaz bir hale getirmektedir. Dolayısıyla güvenilir kabul edilen hadis kaynakları, hiç de zannedildiği gibi güvenilir değildir... $\mathrm{Bu}$ hadisleri toplayanlar, hadis rivâyetlerinin Kur'an'a uygunluğunu gerektiği gibi gözetmedikleri gibi kendi içinde tutarlı olmalarını da gerektiği gibi gözetmemişlerdir. Tek başına bu bile hadis rivâyetlerinin tamamına yakınının Peygamberimize ait olmadıklarının ve ondan çok sonra uydurulduklarının yeterli delilidir. $\mathrm{Bu}$ yüzden hadis rivâyetlerine güvenmek mümkün değildir.” (Dorman, 2018: 91-92).

Yazara göre, Kütüb-i Sitte olarak bilinen meşhur ve güvenilir kabul edilen hadis kitaplarında geçen birçok hadis, en başta Kur'an ile sonra akıl ve insan tabiatı ile sonra da kendi aralarında çelişir (Dorman, 2018: 95. Yazar, İslam $\mathrm{Ne}$ değildir adlı eserinde de "İ̀lâm, rivayet dini değildir" başlığı altında Kur'an'la yetinebileceğini ve hadis eleştirisini sürdürmüştür. Bk. Dorman, 2018:162-208).

Ahmet Aslan, “Hadisler Kur'an'ın şirkidir” başlığı altında hadisleri inkâr etmiştir. Hadisleri bütünüyle inkâr ederek fikirlerini şöyle ifade etmiştir: "Maalesef şu an sünnî inancında meşruiyet kazanmış Kur'an'ın zıddı olan hadis denen rivayetler, Sünni Müslümanların inanç sisteminde taht kurmuş durumdadır. Dolayısıyla Kur'an'a gerçek inanmanın ve tasdik etmenin yolu hadis denen rivayetlerin reddiyle gerçekleşir" (Aslan, 2020: 11).

Kur'an Müslümanlığı savunan yazar, Buhârî’yi hadis uydurukçusu olarak nitelendirmiştir (Aslan, 2020: 15).

\section{Sonuç}

Sonuç olarak şunu söyleyebiliriz ki, sadece Kur'an'la yetinilebileceğini, sünnetin reddi ile ilgili düşüncesini iddia eden marjinal ve küçük bazı gruplar günümüzde olduğu gibi, tarihin çeşitli dönemlerinde de görülmüştür. İlk dönemlerde bireysel manada olan bu hareketler 19. Yüzyıldan sonra müsteşriklerin etkisiyle Hindistan, Mısır gibi ülkelerde yaygınlaşmıştır. Müslümanların birlikteliğini sağlayacak olanın sadece Kur'an olduğu, hadislerin ise bu amacın önünde birer engel oldukları fikri yerleştirilmeye gayret edilmiştir. Sünneti/hadisi engel gören kimselerden bazıları, hadislerin tümünü inkâr ederlerken bazıları ise hadislerin yeniden değerlendirmeye tabi tutularak sahih rivâyetlerin zayıf rivâyetlerden ayrılmasını gündeme getirmişlerdir.

Kur'an ile yetinme söyleminin bir takım çıkmazları vardır. Sadece Kur'an ile yetinme demek, Hz. Peygamber'in tebyîn görevini elinden alıp sadece tebliğ görevi ile iktifa etmek demektir. Kur'an emirlerini sözlü ve pratik olarak izah etmek ve dinî konularda hüküm vermek Hz. Peygamber'in görevleri arasında yer alır. Kur'an ile yetinme söylemini dillendiren çevreler, Resûlullah'ın konumu ile alakalı âyetleri parçacı yaklaşımla işlemekte, Hz. Peygamber'in statüsünü adeta bir arac1/ postacı durumuna indirgemektedir.

Ayrıca Hz. Peygamber'in Kur'an'da olmayan birçok uygulamaları mevcuttur. Örneğin hac ve oruç gibi hükümlerin aslı Kur'an'da olmasına rağmen bunlarla ilgili çoğu hükümler sünnetle belirtilmiştir. Sünneti reddedenler aslında Kur'an'ın pratiğini de reddetmiş oluyorlar. Dolayısıyla sahih sünnetin itibarsızlaştırılması, Kur'an'ın da itibarsızlaştırılması sonucuna götürür. İslâm dininin esası Kur'an ve sünnete dayanmaktadır. Bu iki asıldan birini kabul etmemek dinin bir kısmını kabul edip diğer bir kısmını inkâr etmek anlamına gelir.

Hz. Peygamber'den gelen rivâyetlerin güvenilir olmadığ 1 fikri ise, hadis âlimlerinin hadislerin sıhhatini tespit konusunda yaptıkları çalışmaları görmezden gelmek anlamına gelir. Zira hicri ikinci asırdan itibaren muhaddislerin hadislerle ilgili titiz çalışmaları onların bu husustaki üstün gayretlerini bizlere sunmaktadır. Muhaddisler, hadislerin zayıflarını sahihlerinden, illetli olanlarını sağlam olanlarından ayırmışlar, mevzu olanları ayıklamışlar ve bunları tespit etmenin prensiplerini açıklamışlar.

\section{Kaynakça}

Ahmed b. Hanbel. (1416/1995). el-Müsned. (Ş. el-Arnavût v.dğr. Thk.) Beyrut: Müessesetü'r-Risâle.

Aslan, A. (2020). Lâ Hadis. İstanbul: Ozan Yayıncılık.

A'zamî, M. M. (1413/1992). Dirâsât fi'l-Hadisi'n-Nebevî. Beyrut: el-Mektebü'l-İslâmî.

A’zamî, M. M. (1987). “Sünneti Inkâr Edenler”. (N. Topaloğlu, Çev.) Dokuz Eylül Üniversitesi İlahiyat Fakültesi Dergisi, 4, 433-456.

Bilgin, A. (2018). Kur'an'l Tanımak: Tarih-Dil-Yorum. Ankara: Araştırma Yayınları.

Çakın, K. (1998). Hadis Inkârcıları. Ankara: Seba Yayınları.

Çelik, A. (1997). “Kur'ân ve Sünnet Bütünlüğü”. Diyanet İlmi Dergi, 33/2, 27-37.

Çelik, H. (2019). Sünnete Farklı Yaklaşımlar. İstanbul: Hiperyayın.

Daudî, Z. (1995). Pakistan ve Hindistan'da Hadis Çalışmaları. İstanbul: İnsan Yayınları.

Demir, Ş. (2002). Kur'an'ın Yeniden Yorumlanması. İstanbul: İnsan Yayınları.

Dorman, E. (2018). Allah'a Öğretilen Din. İstanbul: İstanbul Yayınevi. 
Dorman, E. (2018). Íslam Ne değildir. İstanbul: İstanbul Yayınevi.

Ebû Dâvûd, S. (1419/1999). Sünenü Ebî Dâvîd. Riyad: Beytu Efkâru'd-Devliyye.

Eren, A. C. (2000). “Başlangıcından Günümüze Kur’an Tefsirinde Sünneti Devre Dışı Bırakan Hareketler". Kur'an ve Tefsir Araştırmaları I. 35-59. İstanbul: Ensar Neşriyat.

Görmez, M. (2000). Sünnet ve Hadisin Anlaşılması ve Yorumlamasinda Metodoloji Sorunu. Ankara: Türkiye Diyanet Vakfi Yayınları.

Hâkim en-Nîsâbûrî. (ts.). el-Müstedrek ale's-Sahîhayn. Beyrut: Dâru'l-Marife.

Hansu, H. (2004). Mutezile ve Hadis. Ankara: Kitâbiyât Yayınları.

Hekim, M. T. (1985). Sünnetin Etrafindaki Şüpheler. (H. Aslan, Çev.) İstanbul: Pınar Yayınları.

Irakî, Z. A. (1410/1990). el-Müstahrec ala'l-Müstedrek. thk. Muhammed Abdulmünim. Kahire: Mektebetu's-Sünne.

İbn Mâce, E. M. (ts.). es-Sünen. (M. Fuâd Abdülbâkî, Thk.) Beyrut: Dâru'l-Fikr.

Mevdûdî, E. (1997). Sünnetin Anayasal Niteliği. (N. A. Asrar, Çev.) İstanbul: Bengisu Yayınları.

Nedvî, S. (2002). "Sünnet'i Anlamaya Çalışmak ve Sünnet'e Olan İhtiyaç: Tahkîku Ma'ne's-Sünne ve Beyânu'l-
Hâceti Illeyha”. (M. Kavaklığlu, Çev.) Çorum Ilahiyat Fakültesi Dergisi, 273-293.

Özdemir, A. (2018). İbâdiyye 'nin Ana Hadis Kaynağı Rebî' b. Habîb’in Müsnedi. Şırnak: Şırnak Üniversitesi Yayınları.

Sancaklı, S. (2013). Sünneti Doğru Anlamak. İstanbul: Rağbet Yayınları.

Şâfiî, E. M. (1422/2001). el-Umm. (R. F. Abdulmuttalib, Thk.) Kahire: Dâru'l-Vefâ.

Taberânî, S. (1404/1983). el-Mu'cemu'l-Kebîr. ( Hamdî b. Abdilmecîd es-Silefî, Thk.) Kahire: Mektebetü İbn Teymiyye.

Tirmizî, M. (ts.). Sünenü't-Tirmizî. (A. M. Şakir, Thk.) Beyrut: Dâru İhyâi’t-Turasi'l-Arabîyye.

Yıldırım, E. (2003). "Sünnet veya Rivâyet Karşıtı Söylemlerin Tarihi”. İslâm'ın Anlaşılmasında Sünnetin Yeri ve Değeri, Kutlu Doğum Sempozyumu 2001. 155188. Ankara: Türkiye Diyanet Vakfı Yayınları.

Yüksel, E. (2016). Müslüman Din Adamlarına 19 Soru. İstanbul: Ozan Yayıncılık. 


\section{Extended Abstract}

In this study, the historical background of the discourse of confining oneself to the Quran and its reflections on today is briefly discussed. The discourse of confining oneself to the Quran/the denial of hadiths is an issue that has been discussed by Muslims more or less in every era. Just as there are marginal groups adopting a negative attitude towards sunnah nowadays, there have been certain factions over the course of history which have designated themselves as "Quranic Islam" or "Quranic Muslimhood". They do not accept sunnah, and they secretly or explicitly claim that Islam consists of the Quran alone.

It has been revealed that the tendency to confine oneself to the Quran and not attach importance to sunnah can be traced back to the early days of Islam. The first community to collectively adopt a negative attitude towards hadiths is said to be the Kharijites. Although the Kharijites are said to have denied the hadiths, it is not possible to say that their denial covered all hadiths. While they did not reject the hadiths altogether, they did not accept the narrations of most of the Companions of the Prophet (the sahaba) as they were deemed to have been involved in sedition (fitna).

The second community is the Shia sect. Despite the fact that there are those among them who went too far and rejected the hadiths, they cannot be said to have wholeheartedly rejected the hadiths either. They preferred to accept the hadiths narrated by the Ahl al-Bayt rather than accepting every hadith. They accepted the narrations from some other Companions that did not contradict their own views. The Mutazilah sect did not completely reject hadiths either, yet they rejected some of them under the pretext of textual criticism. Apart from the sects, it has been noted that some individuals approach the hadiths with skepticism and that they do not agree to accept any source other than the Quran.

In the early period, this negative approach towards the hadiths was not collective but individual, not universal but regional. However, this viewpoint has expanded over time and gained social status. When the time period during which Imam Shafi'i (d. 204/820) lived is considered, it is clear that the tendency to confine oneself to the Quran and to reject sunnah was also present in this period. In other words, denial of hadiths is understood to have become a common view in the late 8th and early 9 th century.

A small group in favor of rejecting and denying sunnah is reported to have existed around the end of the second Hijri century. This group was able to survive until the end of the second century or as late as the middle of the third century. After that time, it has been observed that no other group was involved in such a movement. The Islamic world lived free of this sedition for as much as eleven centuries. This situation ended with the beginning of the colonial period. The ideology of rejecting hadiths can be said to have reached a climax in the 19th century. The 19 th century was a century during which important centers of civilization in the Islamic world were invaded. Two of these centers are of particular interest: India and Egypt. India was occupied by the British in 1849, with Egypt following suit in 1882. Confrontation with colonizers gave rise to questioning. In both countries, different approaches and methods were explored to enable Muslims to rise up again, to develop like western nations, to overcome intellectual stagnation, and most importantly, to introduce Islam as a universal religion, first for themselves, and then for the whole of humanity. This approach led Muslims to gather around the Quran and reinterpret it. Meanwhile, the hadiths were subjected to significant criticism for various reasons, and in some cases it was argued that they should be abandoned altogether.

The interest of orientalists in sunnah began in the 1800s, and the first impacts of studies on this matter manifested themselves in India and Egypt, which were both occupied by the British. First, an ideology emerged in India that completely rejected the hadiths and sunnah (Quraniyyun). Although these people, who named themselves "Ahl al-Quran", had different views on many topics, they agreed on two issues: that they should confine themselves to the Quran and that sunnah cannot be considered as proof (hujjah) in religion.

In Egypt, a similar movement of renewal and convergence around the Quran started at the same time, with the same concerns. First, Jamaluddin Afghani (d. 1897) formed a school against British colonialism under the name of Al-Madrasatu'lIslahiyah or the School of Modern Rationalism. This movement, initiated by Afghani in Cairo, invited all humanity to the renewal of Islam. Then, while in exile in Europe, together with his student Muhammad Abduh (d. 1905), he used his publications to invite Muslims to an Islamic awakening and liberation from colonialism by nourishing themselves with their own sources. The message and work of Abduh, who undertook the leadership of the Islamic renewal (tajdid) movement that was initiated after his return to Egypt, was entirely Qurancentered. According to Abduh, the fact that the narratives (khabar) are in reliable sources of hadith does not give any indication. Rashid Rida (d. 1935), a student of Abduh, drew hadith and sunnah to the center of the religious discussion in Egypt through the journal Manar. After Rashid Rida, his students also rejected sunnah completely.

It seems almost impossible to claim that there were intense discussions around hadiths in Turkey until the last quarter of the twentieth century. In his 1926 article, Religious and NonReligious Narratives, Zakir Kadiri (d.1954) was the first to say that in the determination of hadiths, importance should be attached to the narrators of hadiths, that the texts were neglected, and that the hadiths were not criticized sufficiently. Besides these methodical studies, there are also those who reject the whole corpus of hadiths.

In conclusion, the discourse of confining oneself to the Quran has some dilemmas. Confining oneself to the Quran means taking away the duty of explanation (tabyin) of the Holy Prophet and confining him to his duty of conveyance (tabligh). Explaining the orders of the Quran verbally and practically and deciding on religious matters are among the duties of the Prophet. The circles that voice the discourse of confining oneself to the Quran are addressing the ayahs related to the status of the Prophet with a separationist approach, and are reducing the status of the Prophet to something of a mediator or courier.

The idea that the narrations from the Prophet are not reliable means ignoring the endeavors of the hadith scholars to determine the soundness of the hadiths. Yet, the meticulous studies of the hadith scholars (muhaddith) as of the second century of Hijra demonstrate to us their great efforts in this regard. Hadith scholars distinguished the false hadiths from the authentic (sahih) ones, the flawed ones (illah) from the sound ones, eliminated the fabricated (mawdu) ones, and explained the principles of determining them. 